\title{
Perbedaan Kebersihan Sepertiga Apikal Saluran Akar dari Smear Layer Menggunakan Sistem Aktivasi Ultrasonik dan Sonik
}

\author{
Puspita $\mathrm{D}^{1}$, Djuanda $\mathrm{R}^{1}$, Evelyna $\mathrm{A}^{1}$
}

1.Fakultas Kedokteran Gigi, Universitas Kristen Maranatha, Bandung, 40164, Indonesia

Email: deladonnapuspita@gmail.com

\begin{abstract}
Abstrak
Aktivasi larutan irigasi sangat berpengaruh terhadap keberhasilan perawatan endodontik. Teknik aktivasi dibagi menjadi dua, manual dengan menggunakan jarum dan mekanis dengan aktivasi ultrasonik dan sonik. Tujuan dari penelitian ini adalah untuk melihat perbandingan kebersihan sepertiga apikal saluran akar dari smear layer menggunakan teknik aktivasi ultrasonik dan sonik.

Penelitian ini menggunakan 15 buah gigi premolar mandibula. Bahan irigasi yang digunakan adalah 2,5\% $\mathrm{NaOCl}$ dan $17 \%$ EDTA. Sampel dibagi menjadi 3 kelompok berdasarkan teknik aktivasi yang digunakan: kelompok I: irigasi manual; kelompok II: aktivasi ultrasonik; III: aktivasi sonik. Gigi yang telah dipreparasi dibelah secara longitudinal untuk melihat tubuli dentin pada bagain sepertiga apikal saluran akar menggunakan SEM dengan perbesaran 2000x dan data yang didapat dianalisis dengan menggunakan metode Kruskal Wallis dan Mann Whitney.

Hasil penelitian kebersihan pada sepertiga apikal saluran akar menggunakan statistik Mann Whitney menunjukan adanya perbedaan kebersihan yang signifikan antara kelompok II dan III dengan nilai $\mathrm{p}<0,05$. Kelompok III lebih bersih dibandingkan kelompok II.

Teknik aktivasi sonik lebih efektif dalam membersihkan sepertiga apikal saluran akar dari smear layer dibandingkan dengan teknik ultrasonik. Perlu diperhatikan penggunaan bahan irigasi dan aktivasi yang bervariasi.
\end{abstract}

\section{The Differences in Hygiene of the Apical Third Root of the Smear Layer Using Ultrasonic and Sonic Activation System}

\begin{abstract}
Irrigant activation is important for successful endodontic treatment. There are some of activation technique those are manual irrigation with needle irrigation and mechanics irrigation with sonic, and ultrasonic activation. The aim of this study was to compare the effectiveness between sonic and ultrasonic activation technique as irrigation activation for smear layer removal in apical third of the root canal.

Fifteen mandibular premolars were used. NaOCl 2,5\% and EDTA $17 \%$ was used as an irrigant. Sample were divided into 3 equal group ( $n=5)$ according to the final activation technique: group I as a needle irrigation II as a ultrasonic activation, group III sonic activation. Root canals were split longitudinnaly and subjected to scanning electron microscope with 2000x magnification. Data were evaluated using statistics kruskall wallis and mann whitney.

The result of this study shows there were statistically significant differences in staistics Mann Whitney on group III were more clean than group II $p<0,05$.

Sonic technique more effective in removal of smear layer in apical third of the root canal than ultrasonic activation technicque. Important to noted the variant of irrigant and activation.
\end{abstract}

Keywords: activation techniques; root canal irrigation; smear layer 


\section{Pendahuluan}

Endodontik adalah cabang ilmu kedokteran gigi yang berkaitan dengan morfologi, fisiologi, patologi pulpa gigi dan jaringan periradikular. Studi endodontik mencakup ilmu-ilmu dasar dan klinis, termasuk biologi pulpa normal, etiologi, diagnosis, pencegahan, perawatan penyakit, cedera pulpa dan kondisi periradikular. ${ }^{1}$ Triad endodontik terdiri dari preparasi biomekanik, steriliasi ruang pulpa dan obturasi tiga dimensi, merupakan ciri khas keberhasilan endodontik. ${ }^{2}$ Perawatan endodontik dilakukan untuk desinfeksi seluruh sistem saluran akar yang membutuhkan eliminasi mikroorganisme, komponen mikroba serta pencegahan terjadinya infeksi kembali selama dan setelah perawatan. Tujuan endodontik dicapai dengan debridemen secara kimia dan mekanik, yang sistem mekaniknya dikaitkan dengan larutan irigasi. ${ }^{3}$

Debridemen sistem saluran akar sangat penting untuk keberhasilan endodontik. Irigasi adalah bagian yang sangat penting dari debridemen saluran akar. Pembersihan dan pembentukan saluran akar tidak mungkin sepenuhnya tercapai karena sifat rumit dari anatomi saluran akar, bahkan penggunaan rotatory instrument, nickel-titanium instrument hanya bekerja pada central body saluran akar. Daerah yang tidak terjangkau mungkin menyisakan debris dan mikroba yang mencegah adaptasi dari material obturasi yang dapat menyebabkan inflamasi periradikular yang presisten. $^{2}$

Irigasi berperan dalam memperkuat pembersihan dan desinfeksi di daerah sistem saluran akar yang tidak cukup dipengaruhi oleh instrumen. Pembersihan dan desinfeksi tambahan dilakukan secara kimia dan mekanis dan penghilangan bakteri terutama biofilm, sisa-sisa jaringan pulpa, debris dentin dan smear layer oleh bahan irigasi yang dapat menjangkaunya. Multispesies mikroba biofilm di daerah yang tidak dapat dijangkau pada sistem saluran akar adalah penyebab utama infeksi yang persisten, sehingga menjadi target utama untuk dibersihkan oleh larutan irigasi. ${ }^{4}$

Smear layer merupakan lapisan yang dihasilkan oleh instrumen tangan dan rotatory files yang terdiri dari substansi organik, inorganik, termasuk fragmen dari prosesus odontoblastik, mikroorganisme, dan jaringan nekrotik. Lapisan smear layer menghambat penetrasi dari desinfektan intrakanal dan sealer ke tubulus dentin sehingga harus dibuang dengan menggunakan larutan irigasi. ${ }^{5}$

Larutan irigasi yang umum digunakan dalam endodontik salah satunya yaitu sodium hipoklorit $(\mathrm{NaOCl})$, karena sifat antibakteri dan mampu membuang jaringan organik, namun memiliki kekurangan yaitu tidak mampu untuk membuang substansi inorganik pada smear layer. Asam etilenadiamina-tetraasetat (EDTA) memiliki kemampuan untuk membuang 
substansi inorganik dari debris intrakanal. ${ }^{3}$ EDTA lebih efektif dalam menghilangkan smear layer dibandingkan $\mathrm{NaOCl}{ }^{6}$

Penetrasi bahan irigasi ke dalam saluran akar tergantung pada anatomi saluran akar, teknik aplikasi bahan irigasi, volume larutan, instrumentasi saluran akar dan karakteristik bahan irigasi. ${ }^{7}$ Terdapat beberapa teknik irigasi yaitu manual dan rotatory. Teknik irigasi manual termasuk irigasi dengan jarum, brush, dan manual dynamic agitation dengan files dan guttapercha points. Irigasi dengan rotatory termasuk rotatory brushes, sonik dan ultrasonik. ${ }^{8}$

Teknik ultrasonik pada perawatan endodontik telah meningkatkan kualitas perawatan pada banyak aspek, termasuk akses masuk ke lubang saluran akar, pembersihan, pembentukan, pengisian saluran akar, mengeleminasi material obturasi, intrakanal dan bedah endodontik. Penelitian sebelumnya mengatakan smear layer terbuang dengan ultrasonik, sebaliknya penelitian lainnya menunjukan aktivasi ultrasonik menggunakan $\mathrm{NaOCl}$ tidak efektif dalam membuang smear layer.

Teknik aktivasi sonik terbukti sebagai metode yang efektif untuk desinfeksi saluran akar, sistemnya dapat secara efektif membersihkan saluran utama, membersihkan smear layer dan mempersiapkan pengisian saluran lateral. ${ }^{3}$ Penelitian sebelumnya menunjukan irigasi sonik dan ultrasonik memberi hasil yang lebih baik dalam menghilangkan smear layer pada sepertiga apikal lengkung saluran akar daripada irigasi konvensional. ${ }^{9}$

Baru-baru ini Eddy tip (VDW, Munich, Germany) memperkenalkan sistem aktivasi irigasi bertenaga sonik. Alat tersebut dapat secara efektif membersihkan sistem saluran akar yang kompleks, namun menurut penelitian sebelumnya irigasi menggunakan $\mathrm{NaOCl}$ dengan teknik aktivasi ultrasonik dan teknik aktivasi sonik menggunkan Eddy tip menunjukan hasil yang tidak signifikan dalam menghilangkan smear layer. ${ }^{10}$

Identifikasi masalah penelitian ini adalah apakah terdapat perbedaan kebersihan sepertiga apikal saluran akar dari smear layer menggunakan sistem aktivasi ultrasonik dan sonik.

Tujuan penelitian ini adalah untuk mengukur dan menilai keefektifan sistem aktivasi ultrasonik dan sonik dalam membersihkan sepertiga apikal saluran akar dari smear layer.

Pulpa dibagi menjadi dua bagian yaitu koronal dan radikuler, pulpa koronal terdiri dari tanduk pulpa dan ruang pulpa sedangkan pulpa radikuler merupakan saluran yang terdapat di dalam akar gigi. ${ }^{23}$ Diameter saluran akar cenderung menurun dengan bertambahnya usia, iritasi 
menyebabkan penyempitan lebih lanjut. Bentuk saluran akar sesuai dengan bentuk akar, akar yang bulat dan berbentuk kerucut biasanya hanya memiliki satu saluran akar, tetapi akar yang elips dan memiliki permukaan yang datar atau cekung memiliki lebih dari satu saluran akar. ${ }^{24}$

Saluran aksesori dan lateral memanjang dari pulpa ke periodonsium. Saluran akar aksesori adalah setiap cabang dari saluran akar utama atau ruang yang terhubung dengan permukaan eksternal akar. Saluran akar lateral adalah saluran akar aksesori yang terletak di koronal atau sepertiga tengah akar, biasanya memanjang secara horizontal dari saluran akar utama. ${ }^{25}$ Saluran aksesori terjadi $73,5 \%$ di sepertiga apikal saluran akar. Saluran aksesori terbentuk oleh pembuluh periodontal yang terperangkap dalam selubung akar epitel Hertwig's selama kalsifikasi. ${ }^{26}$ Saluran aksesori berfungsi sebagai jalan untuk iritan terutama dari pulpa ke periodium. Saluran aksesori juga dapat terjadi pada bifurkasi dan trifurkasi gigi multi-akar. ${ }^{27}$

Terminal bagian apikal akar gigi menunjukan empat landmark yang berbeda yaitu konstriksi apikal, foramen apikal, apeks dan cemento-dentinal junction (CDJ). ${ }^{28}$ Foramen apikal merupakan lubang apikal utama pada saluran akar, konstriksi apikal didefinisikan sebagian bagian apikal dari saluran akar dengan diameter tersempit. ${ }^{25} \mathrm{CDJ}$ adalah garis penyatuan antara dentin dan sementum tempat jaringan pulpa berakhir dan jaringan periodontal dimulai. ${ }^{28}$

Jarak antara konstriksi apikal dan foramen apikal berkisar antara 0,4 -1,2 mm sedangkan jarak dengan apeks berkisar 0,5-1,01 mm. Konstriksi apikal terletak di dentin atau di tingkat CDJ. Bentuk konstriksi apikal di bagian longitudinal memiliki empat konfigurasi yaitu single, tapered, multi-konstriksi dan pararel. Bagian horizontal, dimensi labio-lingual saluran akar di konstriksi apikal lebih besar daripada dimensi mesio-distal sebesar 0,05 mm. Bentuk saluran akar yang paling umum di konstriksi apikal adalah bundar atau oval. Jarak rata-rata antara foramen apikal dan apeks ditemukan kurang dari $1 \mathrm{~mm}$. Frekuensi deviasi foramen apikal terjadi karena penuaan dan pengendapan sementum. ${ }^{28}$

Saluran akar berbentuk oval atau irregular pada sepertiga apikal saluran akar, dan diameter terbesarnya terdapat pada aspek bukolingual. ${ }^{29}$ Ketebalan dentin radikular lebih besar pada permukaan lingual akar, dan ketebalan dinding tipis pada sepertiga apikal saluran akar. ${ }^{30}$ Pada pengisian saluran akar banyak area saluran akar terutama pada regio apikal tidak tersentuh selama preparasi saluran akar karena bentuk oval atau irregular dari saluran akar bagian apikal. ${ }^{31}$ Saluran akar yang tidak terinstrumentasi pada bagian apikal menyimpan mikroflora yang dapat menyebabkan inflamasi periradikular. ${ }^{32}$

Pembersihan saluran akar bertujuan untuk mengurangi iritan. ${ }^{15}$ Tujuan pembentukan saluran akar adalah untuk memfasilitasi pembersihan dan menyediakan ruang untuk menempatkan bahan-bahan pengisi. Tujuan utama pembentukan adalah mempertahankan bentuk saluran akar dari orifis ampai apex. Pembentukan saluran akar ditentukan oleh dimensi saluran akar sebelum perawatan, teknik obturasi, dan rencana perawatan restoratif. ${ }^{35}$

Selama pembersihan dan pembentukan saluran akar, material pulpa organik dan debris inorganik menumpuk di dinding dentin saluran akar radikuler yang menghasilkan lapisan smear layer amorf yang tidak beraturan. ${ }^{37}$ Pada pulpa nekrosis smear layer dapat terkontaminasi oleh bakteri dan metaboliknya. ${ }^{23}$

Debris organik pada smear layer merupakan substrat untuk pertumbuhan bakteri dan dapat menghambat kontak sealer dengan dinding saluran akar dan memungkinkan kebocoran. Mikroorganisme yang hidup dalam tubulus dentin dapat menjadikan smear layer sebagai substrat untuk bertumbuh. Lapisan smear layer yang tidak dihilangkan akan secara perlahan hancur bersamaan dengan bahan obturasi yang bocor, atau mungkin hilang oleh enzim dan asam yang dihasilkan oleh bakteri hidup yang tertingal dalam tubulus atau yang masuk melalui kebocoran koronal. Smear layer yang terdapat di dalam saluran akar dapat mengganggu aksi dan keefektifan bahan irigasi dan desinfektan. ${ }^{35}$

Smear layer yang dibuang bahan pengisi dapat beradaptasi lebih baik pada saluran akar. Pembuangan smear layer dapat meningkatkan adhesi sealer ke dentin dan tubular dan 
memungkinkan penetrasi semua sealer pada kedalaman yang bervariasi. Pembuangan smear layer menguragi kebocoran koronal dan apikal. ${ }^{38}$

Schlider et al. menekankan perlunya pembersihan meyeluruh sistem saluran akar yaitu dengan menghilangkan semua substansi dari seluruh ruang saluran akar dengan instrumentasi dan irigasi yang maksimal. Pembersihan dan pembentukan saluran akar tidak hanya berhubungan dengan anatomi dari masing-masing saluran akar tetapi berkaitan juga dengan teknik dan banan untuk memperoleh hasil akhir. ${ }^{46}$

Gelombang getaran ultrasonik dapat digunakan sebagai aktivasi bahan irigasi saluran akar dengan menggunakan handpiece ultrasonik. Handpiece ultrasonik meneruskan sound wave ke files endodontik yang menghasilkan getaran 25.000 getaran/detik menyebabkan acoustic streaming dari larutan irigasi. ${ }^{57}$ Acoustic streaming merupakan shockwaves yang dihasilkan dengan kecepatan lebih dari 5000mph dalam larutan. ${ }^{55}$

Larutan irigasi mencapai efek biologis-kimia aktif ketika mengalami ultrasonasi seperti kavitasi dan acoustic streaming. Kavitasi terjadi ketika energi ultrasonik menciptakan gelembung yang membesar ke titik tertentu kemudian collapse. Collapse dari gelembung tersebut menghasilkan pressure-vacuum effect yang membersihkan saluran akar yang irregular dan membunuh mikroorganisme. Efek kavitasi merupakan penyebaran energi fisik yang mengarah ke acoustic streaming. Acoustic streaming meningkatkan pembersihan dan 
desinfeksi. Ketika gelombang ultrasonik diproyeksikan dalam cairan, tercipta tekanan negatif yang menyebabkan gelembung collaps, kavitasi menciptakan gelembung yang berosilasi dalam gelombang ultrasonik, ketika gelombang ultrasonik berlanjut gelembung tersebut membesar dan menjadi sangat tidak stabil dan akhirnya collaps dalam kekuatan tinggi. Implikasi dari shockwaves berkekuatan tinggi tersebut memancarkan gelombang bertenaga tinggi dengan kecepatan 25.000-30.000 kali per detik $(25-30 \mathrm{kHz}){ }^{55}$

Pembuangan debris dari dinding saluran akar terjadi melalui kavitasi yang terjadi dalam larutan irigasi. Irigasi ultrasonik dibagi menjadi dua jenis, yang pertama adalah kombinasi dari instrumentasi simultan dan irigasi ultrasonik (UI), yang kedua beroprasi tanpa instrumentasi simultan dan disebut sebagai Passive Ultrasonic Irrigation (PUI). ${ }^{54}$

PUI lebih efektif daripada irigasi menggunakan syringe dan needle dalam membuang sisasisa jaringan pulpa dan debris dentin. PUI lebih efektif karena kecepatan dan volume aliran irigasi yang jauh lebih tinggi yang tercipta di saluran akar selama irigasi ultrasonik. Ultrasonik dapat secara efektif membersihkan debris dan bakteri dari sistem saluran akar, tetapi tidak dapat secara efektif melewati apical vapor lock. ${ }^{57}$

Irigasi sonik beroperasi pada frekuensi yang lebih rendah dibandingkan dengan irigasi ultrasonik (1-6 kHz). EndoActivator merupakan salah satu bentuk irigasi sonik yang menggunakan tip non-cutting polimer, dengan cepat mengagitasi larutan irigasi selama perawatan. EndoActivator merupakan metode yang efektif untuk membersihkan saluran akar. ${ }^{56}$

Eddy (VDW, Munich, Jerman) merupakan sistem aktivasi irigasi bertenaga sonik yang terbuat dari polimer yang fleksibel dengan ukuran 25,04. Eddy memungkinkan pembersihan sistem saluran akar yang kompleks secara efisien. Eddy diaktifkan dengan kekuatan 5000-6000 $\mathrm{Hz}$ oleh air scaler. Eddy menghasilakan gerakan tiga dimensi yang memicu acoustic streaming. ${ }^{10}$

Vibringe (Vibringe BV, Amsterdam, Belanda) adalah sistem irigasi sonik yang mengkombinasi getaran yang digerakkan oleh baterai dengan larutan irigasi saluran akar yang dioperasikan secara manual. Vibringe menggunakan jenis syringe dan needle tradisional tetapi menambahkan getaran sonik. ${ }^{58}$

\section{Metode Penelitian}

Alat yang digunakan dalam penelitian ini: Handscoon; Masker; Handpiece; Alat dasar (kaca mulut, eksplorer, pinset dan ekskavator); Sonde lurus; Endo Burs; K-File \#10 \#15; ProTaper gold S1, S2, F1, F2,F3; Endoultra; Eddy tip (VDW, Munich, Germany); Syringe; Jarum irigasi; Paper point; Diamond disk; Chisel; dan SEM (Scanning Electron Microscope).

Bahan yang digunakan dalam penelitian ini: Gigi premolar rahang bawah manusia; Larutan irigasi EDTA 17\% (asam etilenadiamina-tetraasetat); dan Larutan $\mathrm{NaOCl} \mathrm{2,5 \%} \mathrm{(sodium}$ hipoklorit).

Penelitian ini bersifat eksperimental laboratorik, data dianalisis meggunakan metode nonparametrik Kruskal Wallis, dan dilanjutkan dengan uji Mann-Whitney.

Desain penelitian pada penelitian ini menggunakan studi Scanning Electron Microscope (SEM) dengan mengindentifikasi kebersihan smear layer pada bagian sepertiga apikal saluran akar. Pada penelitian ini sampel diirigasi dengan teknik yang berbeda, dibagi menjadi 4 kelompok yaitu: Kelompok I Sebagai kelompok kontrol diirigasi menggunakan syringe dengan jarum irigasi 30 gauge close ended dan $\mathrm{NaOCl} 2,5 \%$ + EDTA 17\%. Kelompok II Irigasi menggunakan PUI (Passive Ultrasonic Irrigation) dan $\mathrm{NaOCl} 2,5 \%$ + EDTA 17\%. Kelompok III Iirigasi menggunakan aktivasi sonik Eddy dan $\mathrm{NaOCl} 2,5 \%$ + EDTA $17 \%$.

Pada bagian luar permukaan gigi buat groove longitudinal menggunakan diamond disk tanpa menembus saluran akar, dengan bantuan chisel pecah gigi menjadi dua bagian. Bagian apikal 
yang akan dianalisis diamankan pada metal stub. Akar yang tidak dipreparasi menghadap ke holder dengan sejajar, kemudian sampel mamasuki tahap coating Pd Au agar lebih konduktif pada saat dilakukan pemeriksaan menggunakan SEM (Scanning Electron Microscope).

Penilaian smear layer diidentifikasi menggunakan Scanning Electron Microscope. Sampel dimasukkan ke dalam specimen chamber selanjutnya dilakukan pengamatan dan pengambilan gambar pada bagian sepertiga apikal dengan perbesaran 2000x. Penilaian kebersihan smear layer: Skor 1 : seluruh tubuli dentin terbuka; Skor 2 : lebih dari 50\% tubuli dentin terbuka; Skor 3 : kurang dari 50\% tubuli dentin terbuka; dan Skor 4 : hampir seluruh tubuli dentin tertutup oleh smear layer.

Data yang diperoleh dari penelitian ini dimasukan ke dalam tabel untuk pengamatan dan pengkajian data. Data kemudian dianalisis dan diolah menggunakan metode non-parametrik Kruskal Wallis untuk menentukan perbedaan peringkat secara statistik pada variabel independen berskala kategorik lebih dari 2 kelompok dilanjutkan dengan uji Mann-Whitney untuk menilai apakah perbedaan tersebut signifikan atau tidak pada 2 kelompok menggunakan perangkat lunak SPSS. 


\section{Hasil Penelitian}

Hasil penelitian dibagi menjadi 3 kelompok. Kelompok I sebagai kelompok kontrol diirigasi menggunakan syringe dengan jarum irigasi 30 gauge close ended dan $\mathrm{NaOCl} 2,5 \%+$ EDTA 17\%. Kelompok II irigasi menggunakan PUI (Passive Ultrasonic Irrigation) dan $\mathrm{NaOCl} 2,5 \%$ + EDTA 17\% Kelompok III irigasi menggunakan aktivasi sonik Eddy dan $\mathrm{NaOCl} 2,5 \%+$ EDTA $17 \%$.

\section{Gambaran Scanning Electron Microscope (SEM) Sepertiga Apikal Saluran Akar}

Penelitian menggunakan SEM dengan perbesaran 2000x pada sepertiga apikal saluran akar pada masing-masing kelompok penelitian.

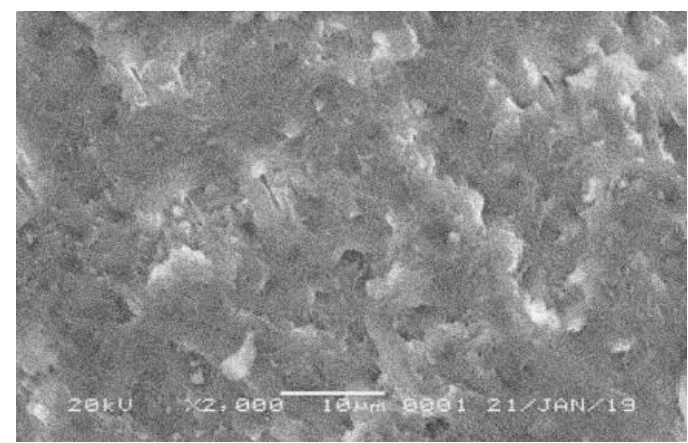

Gambar 1 Gambaran Mikroskopis Sepertiga Apikal Saluran Akar Kelompok I

Hasil SEM sepertiga apikal saluran akar dengan perbesaran 2000x pada kelompok syringe menunjukan bahwa seluruh tubuli dentin tertutup oleh smear layer.

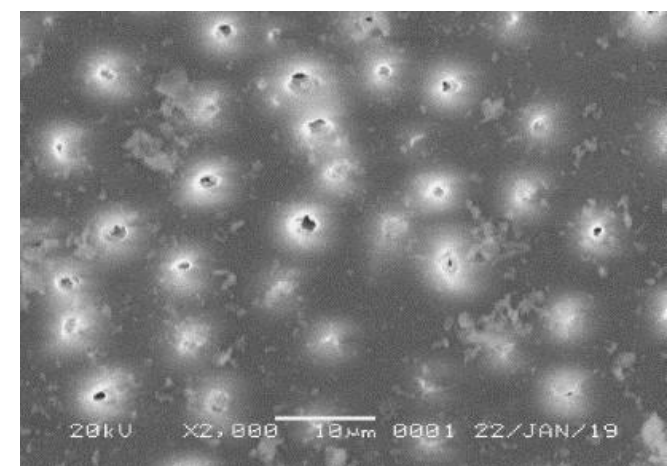

Gambar 2 Gambaran Mikroskopis Sepertiga Apikal Saluran Akar Kelompok II 
Hasil SEM sepertiga apikal saluran akar dengan perbesaran 2000x pada kelompok ultrasonik menunjukan bahwa beberapa tubuli dentin sudah terbuka, namun sebagian besar masih tertutupi dengan smear layer.

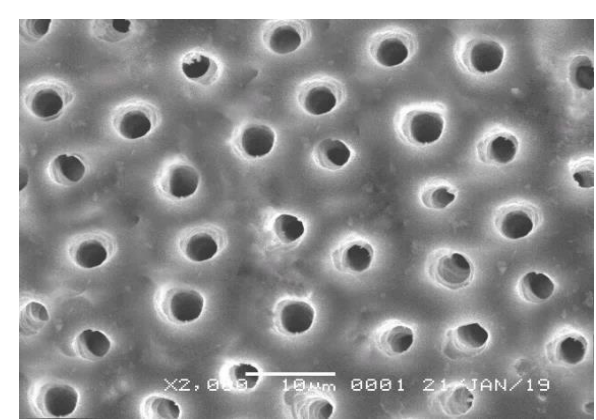

Gambar 3 Gambaran Mikroskopis Sepertiga Apikal Saluran Akar Kelompok III

Hasil SEM sepertiga apikal saluran akar dengan perbesaran 2000x pada kelompok sonik menunjukan bahwa sebagian besar sudah terbuka.

Hasil analisis rata-rata skor kebersihan sepetiga apikal saluran akar dari Smear Layer dalam penelitian dapat dilihat pada Tabel I.

Tabel I Rata-rata dan Standar Deviasi Skor Kebersihan Sepetiga Apikal Saluran Akar dari Smear Layer Berdasarkan Kelompok Perlakuan

\begin{tabular}{lcc}
\hline \multicolumn{1}{c}{ Kelompok } & Rata-rata & SD \\
\hline Syringe $\mathrm{NaOCl} 2,5 \%+$ EDTA 17\% & 3.6 & 0.548 \\
PUI NaOCl 2,5\% + EDTA 17\% & 2.4 & 0.548 \\
Aktivasi sonik Eddy NaOCl 2,5\% + EDTA 17\% & 1.4 & 0.548 \\
\hline
\end{tabular}

Grafik 1 Rata-rata Skor Kebersihan Sepetiga Apikal Saluran Akar dari Smear Layer Berdasarkan Kelompok Perlakuan

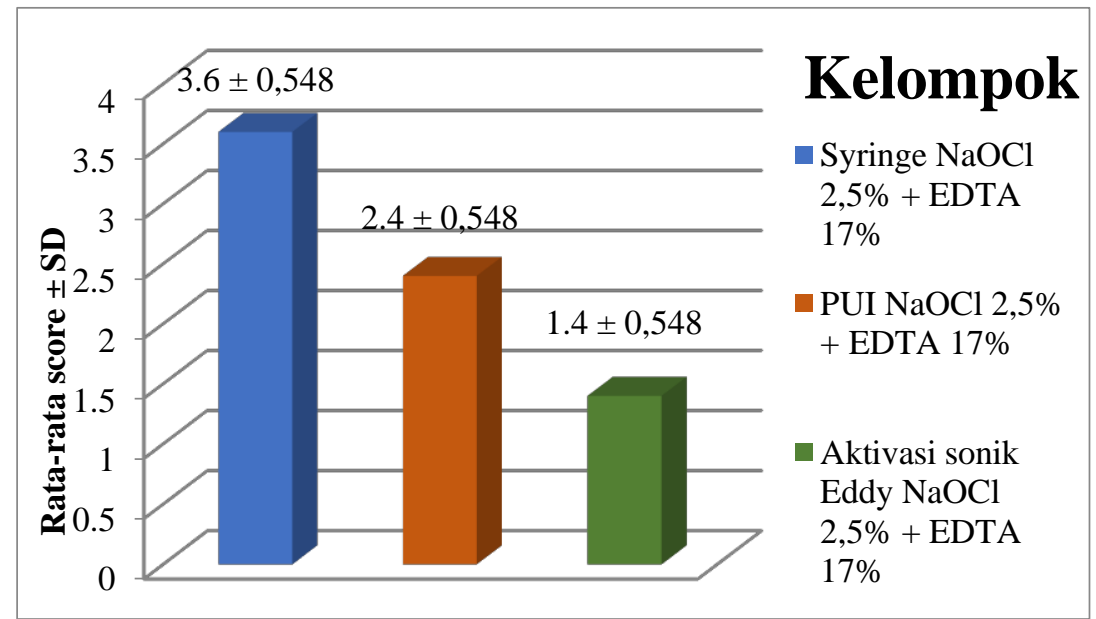


Berdasarkan data pada Tabel I dapat diketahui kelompok Syringe NaOCl 2,5\% + EDTA $17 \%$ memiliki nilai rata-rata skor yang paling besar yaitu 3,6 dengan standar deviasi 0,548, diikuti dengan kelompok PUI NaOCl 2,5\% + EDTA 17\% sebesar 2,4 dan nilai rata-rata terkecil adalah nilai rata-rata kelompok aktivasi sonik Eddy $\mathrm{NaOCl} 2,5 \%$ + EDTA 17\% sebesar 1,4 dengan standar deviasi 0,548 .

Tabel II Distribusi Frekuensi Skor Kebersihan Sepertiga Apikal Saluran Akar dari Smear Layer

\begin{tabular}{ccc}
\hline Score & Jumlah $(\mathbf{n})$ & Persentase $(\boldsymbol{\%})$ \\
\hline Skor 1 & 3 & 20.00 \\
Skor 2 & 5 & 33.33 \\
Skor 3 & 4 & 26.67 \\
Skor 4 & 3 & 20.00 \\
\hline Total & $\mathbf{1 5}$ & $\mathbf{1 0 0 . 0 0}$ \\
\hline
\end{tabular}

Grafik 2 Skor Kebersihan Sepetiga Apikal Saluran Akar dari Smear Layer

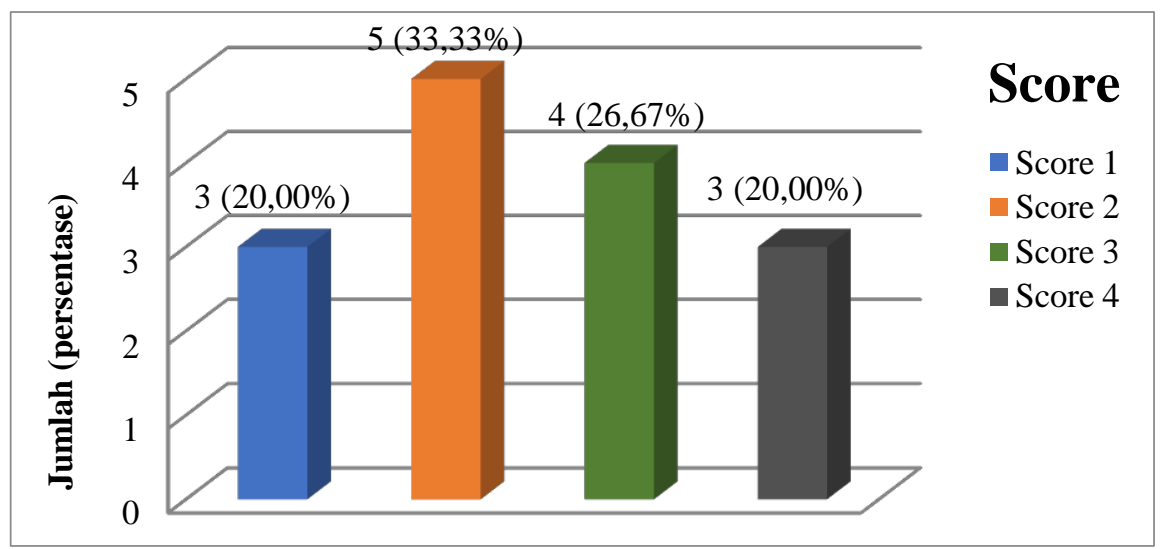

Berdasarkan Tabel II diketahui sebanyak 3 buah (20\%) gigi premolar mandibular memiliki skor kebersihan sepetiga apikal saluran akar dari smear layer 1, sebanyak 5 buah $(33,33 \%$ ) gigi premolar mandibular memiliki skor kebersihan sepetiga apikal saluran akar dari smear layer 2, sebanyak 4 buah $(26,67 \%$ ) gigi premolar mandibular memiliki skor kebersihan sepetiga apikal saluran akar dari smear layer 3 dan sebanyak 3 buah (20\%) gigi premolar mandibular memiliki skor kebersihan sepetiga apikal saluran akar dari smear layer 4.

Uji normalitas dilakukan untuk menghitung sebaran data yang diperoleh pada penelitian. Penelitian ini menggunakan jumlah sampel $<50$ sehingga uji normalitas yang digunakan adalah uji Shapiro-Wilk. Hasil perhitungan uji normalitas disajikan pada tabel berikut: 
Tabel III Hasil Uji Normalitas Data

\begin{tabular}{lcc}
\hline \multicolumn{1}{c}{ Kelompok } & p & Ket. \\
\hline Syringe NaOCl 2,5\% + EDTA 17\% & 0,006 & Tidak Normal \\
PUI NaOCl 2,5\% + EDTA 17\% & 0,006 & Tidak Normal \\
Aktivasi sonik Eddy NaOCl 2,5\% + EDTA 17\% & 0,006 & Tidak Normal \\
\hline
\end{tabular}

Tabel III di atas menunjukkan hasil pegujian normalitas pada masing-masing variabel. Uji normalitas yang digunakan adalah Shapiro-wilk. Berdasarkan hasil pengujian diketahui bahwa ketiga kelompok perlakuan tidak berdistribusi normal dimana nilai $\mathrm{p}(0,006)<$ nilai alpha 0,05 . Sehingga untuk mengetahui perbedaan kebersihan sepertiga apikal saluran akar dari smear layer dengan menggunakan sistem aktivasi ultrasonik dan sonik diuji dengan pengujian statistik Non Parametrik Kruskal Wallis.

Tabel IV Perbedaan Kebersihan Sepertiga Apikal Saluran Akar dari Smear Layer Ketiga Kelompok Perlakuan

\begin{tabular}{lccc}
\hline \multicolumn{1}{c}{ Kelompok } & Chi Square & df & p \\
\hline Syringe $\mathrm{NaOCl} 2,5 \%+$ EDTA 17\% & & & \\
PUI NaOCl 2,5\% + EDTA 17\% & 10.878 & 2 & 0,04 \\
Aktivasi sonik Eddy NaOCl 2,5\%+EDTA 17\% & & & \\
\hline
\end{tabular}

Berdasarkan Tabel IV di atas, diketahui bahwa dari hasil pengujian menggunakan statistik uji Kruskal Wallis didapatkan nilai p-value sebesar $0,04<\alpha(5 \%)$ yang artinya terdapat perbedaan yang signifikan antara kebersihan sepertiga apikal saluran akar dari smear layer ketiga kelompok perlakuan. Selanjutnya dilakukan Pengujian Mann Whitney untuk melihat apakah terdapat perbedaan antara 2 kelompok perlakuan.

Tabel V Perbedaan Kebersihan Sepertiga Apikal Saluran Akar dari Smear Layer Antara Kelompok 1 dan Kelompok 2

\begin{tabular}{lccc}
\hline \multicolumn{1}{c}{ Kelompok } & Mean of Rank & alpha (o) & p \\
\hline Syringe $\mathrm{NaOCl} 2,5 \%+$ EDTA $17 \%$ & 7.60 & 0.05 & 0.020 \\
PU $\mathrm{NaOCl} 2.5 \%+$ EDTA $17 \%$ & 3.40 & & \\
\hline
\end{tabular}

Berdasarkan Tabel V di atas, diketahui bahwa dari hasil pengujian menggunakan statistik uji Mann Whitney didapatkan nilai p-value sebesar $0,020<\alpha(5 \%)$ yang artinya terdapat perbedaan yang signifikan antara kebersihan sepertiga apikal saluran akar dari smear layer 
kelompok 1 (Syringe $\mathrm{NaOCl}$ 2,5\% + EDTA 17\%) dengan kelompok 2 (PUI NaOCl 2,5\% + EDTA 17\%).

Tabel VI Tabel Perbedaan Kebersihan Sepertiga Apikal Saluran Akar dari Smear Layer Antara Kelompok 1 dan Kelompok 3

\begin{tabular}{cccc}
\hline Kelompok & Mean of Rank & alpha (a) & p \\
\hline Syringe NaOCl 2,5\% + EDTA 17\% & 8.00 & 0.05 & 0.007 \\
Aktivasi sonik Eddv NaOCl 2.5\% + EDTA 17\% & 3.00 & & \\
\hline
\end{tabular}

Berdasarkan Tabel VI di atas, diketahui bahwa dari hasil pengujian menggunakan statistik uji Mann Whitney didapatkan nilai pvalue sebesar $0,007<\alpha(5 \%)$ yang artinya terdapat perbedaan yang signifikan antara kebersihan sepertiga apikal saluran akar dari smear layer kelompok 1 (Syringe $\mathrm{NaOCl}$ 2,5\% + EDTA 17\%) dengan kelompok 3 (Aktivasi sonik Eddy $\mathrm{NaOCl} 2,5 \%$ + EDTA $17 \%$ ).

Tabel VII Tabel Perbedaan Kebersihan Sepertiga Apikal Saluran Akar dari Smear Layer Antara Kelompok 2 dan Kelompok 3

\begin{tabular}{|c|c|c|c|}
\hline Kelompok & Mean of Rank & alpha $(\alpha)$ & $\mathbf{p}$ \\
\hline PUI $\mathrm{NaOCl} 2,5 \%+$ EDTA $17 \%$ & 7.40 & 0.05 & 0.031 \\
\hline Aktivasi sonik Eddv $\mathrm{NaOCl} 2.5 \%+\mathrm{EDTA} 17 \%$ & 3.60 & & \\
\hline
\end{tabular}

Berdasarkan Tabel VII di atas, diketahui bahwa dari hasil pengujian menggunakan statistik uji Mann Whitney didapatkan nilai pvalue sebesar 0,031 < $\alpha(5 \%)$ yang artinya terdapat perbedaan yang signifikan antara kebersihan sepertiga apikal saluran akar dari smear layer kelompok 2 (PUI NaOCl 2,5\% + EDTA 17\%) dengan kelompok 3(Aktivasi sonik Eddy $\mathrm{NaOCl}$ $2,5 \%+$ EDTA $17 \%)$.

\section{Diskusi}

Penelitian ini memperlihatkan bahwa teknik sonik lebih efektif dalam membersihkan sepertiga apikal saluran akar dibandingkan dengan teknik ultrasonik. Pada penelitian ini terdapat kelompok I yang merupakan kelompok kontrol, diirigasi tanpa menggunakan aktivasi dan hasilnya memperlihatkan tingkat kebersihan saluran akar pada bagian sepertiga apikal yang lebih kotor dibandingkan kelompok II (aktivasi ultrasonik) dengan nilai $\mathrm{p}<0,05$ sedangkan kelompok III (aktivasi sonik) memperlihatkan tingkat kebersihan saluran akar pada bagian sepertiga apikal yang lebih bersih dibandingkan dengan kelompok II dengan nilai $\mathrm{p}<0,05$

Gambaran Scanning Electron Microscope (SEM) yang digunakan untuk melihat kebersihan sepertiga apikal saluran akar dari smear layer pada masing-masing kelompok memperlihatkan hasil Gambar 1 memperlihatkan bahwa smear layer menutupi seluruh tubuli dentin yang artinya kelompok I mendapatkan skor 4 dari kriteria SEM. Pada Gambar 2 memperlihatkan bahwa sebagian besar tubuli dentin masih tertutupi smear layer, namur beberapa tubuli dentin sudah mulai terlihat, yang artinya kelompok II mendapatkan skor 3 dari kriteria SEM. Pada Gambar 3 memperlihatkan bahwa seluruh tubuli dentin terbuka, yang artinya kelompok III mendapatkan 


\section{skor 1 dari kriteria SEM.}

Irigasi yang aman dan efektif sangat penting untuk keberhasilan perawatan saluran akar. Irigasi memenuhi beberapa fungsi mekanik, kimia, dan biologis yang penting. Instrumentasi sistem saluran akar harus didukung oleh irigasi untuk menghilangkan sisa-sisa jaringan pulpa dan debris dentin. Tantangan untuk irigasi yaitu area yang tidak tersentuh oleh file seperti istmus dan saluran akar lateral, juga area yang luas pada saluran akar yang oval dan datar. Irigasi yang optimal didasarkan pada kemamuannya untuk berpenetrasi ke daerah apikal. ${ }^{55}$

Menurut penlitian yang dilakukan oleh Shen et al. mengatakan bahwa tekanan cairan dalam larutan irigasi berguna dalam membersihkan dinding saluran akar. Terdapat tiga parameter dinamis (pola aliran cairan, kecepatan, tekanan cairan pada dinding saluran akar) semuanya dipengaruhi oleh laju aliran cairan yang ditempatkan pada jarum irigasi. Penelitian dengan jarum irigasi konvensional gagal dalam membersihkan istmus dan saluran akar lateral, sehingga aktivasi irigasi endodontik mejadi langkah yang diperlukan dalam pembersihan sistem saluran akar secara menyeluruh. ${ }^{63}$

Penelitian yang dilakukan oleh Ahmad et al. dengan mengunakan aktivasi ultrasonik untuk meneliti acoustic streaming. Hasil penelitian menunjukan cairan umumnya dipindahkan dari apikal ke ujung koronal files, Kecepatan acoustic streaming terbesar berada di apikal dan yang terkecil di ujung koronal files. Files yang lebih kecil menghasilkan acoustic streaming yang relatif lebih besar, kecepatannya meningkat dengan peningkatan daya. ${ }^{55}$ Hasil penelitian tersebut kemudian dikonfirmasi oleh Jiang et al. saluran akar yang diinstrumentasi dengan metode yang dimodifikasi dengan aktivasi menunjukan permukaan yang lebih bersih. Files yang bergetar bebas menghasilkan hydrodynamic shear stress yang cukup besar untuk menghilangkan debris dan smear layer dari dinding saluran akar. ${ }^{64}$

Penelitian mengenai peningkatan kebersihan dinding saluran akar, saluran akar lateral, dan itsmus, serta pembuangan pasta kalsium hidroksida dan smear layer dengan menggunakan aktivasi sonik memberikan hasil yang baik. Penelitian Sabins et al. melaporkan bahwa irigasi menggunakan aktivasi sonik meningkatkan kebersihan saluran akar dibandingkan dengan menggunakan jarum konvensional. ${ }^{65}$ Menurut penelitian Kanter et al. penggunaan aktivasi sonik menghilangkan lebih banyak debris dan membersihkan saluran akar lateral lebih baik daripada PUI/UI dan jarum irigasi. ${ }^{66}$ Penelitian Rodig et al. melaporkan bahwa penggunaan PUI/UI atau sonik untuk mengaktivasi larutan irigasi $\mathrm{NaOCl}$ dan EDTA pada saluran akar menghasilkan pembuangan smear layer yang lebih baik. ${ }^{67}$

Pada penelitian ini, kelompok aktivasi sonik paling baik dalam membersihkan sepertiga apikal saluran akar karena aktivasi sonik menghasilkan amplitudo yang lebih besar. Amplitudo lebih besar secara signifikan mempengaruhi fenomena hidrodinamik, meskipun aktivasi ultrasonik menghasilkan frekuensi tinggi, tetapi amplitudo pada aktivasi ultrasonik lebih rendah dibandingkan dengan aktivasi sonik. ${ }^{22}$

Penelitian ini menggunakan desain penelitian eksperimental laboratorik yang memiliki kelebihan yaitu pelaksanaan kontrol relatif sempurna dan bias yang sudah dikendalikan dengan menggunakan saluran akar gigi yang lurus dan larutan irigasi yang telah disamakan.

Penelitian ini memiliki kekurangan yaitu harga aktivasi yang relatif mahal dan belum banyak tersedia di pasaran, oleh karena itu pada penelitian selanjutnya diharapkan dapat dilakukan penelitian serupa dengan menggunakan sistem aktivasi yang lebih bervariatif. Kekurangan lainnya yaitu karena penelitian ini dilakukan secara in vitro, terdapat kemungkinan hasil yang berbeda bila dilakukan secara in vivo karena pada penelitian ini tidak terdapat jaringan pulpa dan periapikal yang mempengaruhi debridemen saluran akar sehingga hasil penelitian ini hanya secara relatif dan penelitian selanjutnya sebaiknya dilakukan secara in vivo agar dapat menggambarkan kondisi yang sebenarnya dan meberikan hasil yang lebih relevan. 


\section{Simpulan Penelitian}

Berdasarkan hasil penelitian yang telah dilakukan, maka diperoleh kesimpulan bahwa terdapat perbedaan yang signifikan antara kebersihan sepertiga apikal saluran akar dari smear layer menggunakan sistem aktivasi ultrasonik dan sonik.

\section{Referensi}

1. Elsevier M. Mosby’s Dental Dictionary, Third Edition. Elsevier Inc. 2014.

2. Pasricha SK, Makkar S, Gupta P. Pressure alteration techniques in endodontics-a review of literature. J Clin Diagnostic Res. 2015;9(3):ZE01-ZE06.

3. Plotino G, Cortese T, Grande NM, Leonardi DP, Di Giorgio G, Testarelli L, et al. New technologies to improve root canal disinfection. Braz Dent J. 2016;27(1):3-8.

4. Konstantinidi E, Psimma Z, Chávez de Paz LE, Boutsioukis C. Apical negative pressure irrigation versus syringe irrigation: a systematic review of cleaning and disinfection of the root canal system. International Endodontic Journal. 2017.

5. Mancini M, Cerroni L, Iorio L, Dall'Asta L, Cianconi L. FESEM evaluation of smear layer removal using different irrigant activation methods (EndoActivator, EndoVac, PUI and LAI). An in vitro study. Clin Oral Investig. 2018.

6. Vlad R. Comparison Between Different Endodontic Irrigating Protocols In Smear Layer Removal From Radicular Dentin. Eur Sci J. 2016;12(15):38-43.

7. Article O. Sonic versus ultrasonic activation for the cleaning of the root canal after post space preparation : an in vitro study . 2014;255-62.

8. Gu L sha, Kim JR, Ling J, Choi KK, Pashley DH, Tay FR. Review of Contemporary Irrigant Agitation Techniques and Devices. Journal of Endodontics. 2009.

9. Mohammadi Z, Shalavi S, Giardino L, Palazzi F, Asgary S. Impact of ultrasonic activation on the effectiveness of sodium hypochlorite: A review. Iran Endod J. 2015;10(4):216-20.

10. Urban K, Donnermeyer D, Schäfer E, Bürklein S. Canal cleanliness using different irrigation activation systems : a SEM evaluation. 2017;2681-7.

11. Siqueira JF. Aetiology of root canal treatment failure: Why well-treated teeth can fail. International Endodontic Journal. 2001.

12. Buldur B, Kapdan A. Comparison of the Antimicrobial Efficacy of the EndoVac System and Conventional Needle Irrigation in Primary Molar Root Canals. J Clin Pediatr Dent. 2017;41(4):284-8.

13. L. h. B. Kenneth M. Hargreves. Cohen's Pathays of the pulp. Eleventh. Rotstein Ilan, editor. 2016. 
14. Shuping GB, Ørstavik D, Sigurdsson A, Trope M. Reduction of intracanal bacteria using nickel-titanium rotary instrumentation and various medications. J Endod. 2000.

15. WT Johnson WN. Cleaning and Shaping in: Endodontics: Principles and Practice. 4th ed. 2009.

16. Gomes BPFA, Ferraz CCR, Vianna ME, Berber VB, Teixeira FB, Souza-Filho FJ. In vitro antimicrobial activity of several concentrations of sodium hypochlorite and chlorhexidine gluconate in the elimination of Enterococcus faecalis. Int Endod J. 2001.

17. Ingle, John; Bakland, Leif; Baumgartner JC. Endodontic Principles and Practice. 4th ed. Saunders; 2008.

18. CALT S, SERPER A. Smear Layer Removal by EGTA. J Endod. 2000.

19. Shabahang S, Torabinejad M. Effect of MTAD on Enterococcus faecalis-contaminated root canals of extracted human teeth. J Endod. 2003.

20. Hauser V, Braun A, Frentzen M. Penetration depth of a dye marker into dentine using a novel hydrodynamic system (RinsEndo®). Int Endod J. 2007.

21. Haapasalo M, Shen Y, Wang Z, Gao Y. Irrigation in endodontics. Br Dent J. 2014;216(6):299-303.

22. WALMSLEY AD, LUMLEY PJ, LAIRD WRE. The oscillatory pattern of sonically powered endodontic files. Int Endod J. 1989.

23. Walton RE, Torabinejad M. Principles and Practice of Endodontics 3rd edition. Principles and practice of endodontics. 2002.

24. John I. Ingle Leif K. Bakland JCB. Ingle's endodontics 6. Chapter 29. Root Canal Filling Materials. 2008.

25. AAE. AAE Glossary of Endodontic Terms 2016. Aae. 2016.

26. Vertucci FJ. Root canal morphology and its relationship to endodontic procedures. Endod Top. 2005.

27. Vertucci FJ. Root canal anatomy of the human permanent teeth. Oral Surgery, Oral Med Oral Pathol. 1984;

28. Chandler N, Friedlander L, Alothmani O. The anatomy of the root apex: A review and clinical considerations in endodontics. Saudi Endod J. 2013.

29. Martos J, Ferrer-Luque CM, González-Rodríguez MP, Castro LAS. Topographical evaluation of the major apical foramen in permanent human teeth. Int Endod J. 2009.

30. Bellucci C, Perrini N. A study on the thickness of radicular dentine and cementum in anterior and premolar teeth. Int Endod J. 2002.

31. Weiger R, Bartha T, Kalwitzki M, Löst C. A clinical method to determine the optimal apical preparation size. Part I. Oral Surgery, Oral Med Oral Pathol Oral Radiol 
Endodontology. 2006.

32. Martos J, Tatsch GH, Tatsch AC, MacHado Silveira LF, Ferrer-Luque CM. Anatomical evaluation of the root canal diameter and root thickness on the apical third of mesial roots of molars. Anat Sci Int. 2011.

33. Ingle JI. Endodontics - Volume 1. Endodontics - Volume 1. 2002.

34. Sabeti MA, Nekofar M, Motahhary P, Ghandi M, Simon JH. Healing of Apical Periodontitis After Endodontic Treatment With and Without Obturation in Dogs. J Endod. 2006.

35. Wilcox LR. The relationship of root canal enlargement to finger-spreader induced vertical root fracture. J Endod. 1997.

36. Hulsmann M, Peters OA, Dummer PMH. Mechanical preparation of root canals: shaping goals, techniques and means. Endod Top. 2005;

37. Torabinejad M, Handysides R, Khademi AA, Bakland LK. Clinical implications of the smear layer in endodontics: A review. Oral Surg Oral Med Oral Pathol Oral Radiol Endod. 2002.

38. Çobankara FK, Adanir N, Belli S. Evaluation of the influence of smear layer on the apical and coronal sealing ability of two sealers. J Endod. 2004.

39. Niu W, Yoshioka T, Kobayashi C, Suda H. A scanning electron microscopic study of dentinal erosion by final irrigation with EDTA and $\mathrm{NaOCl}$ solutions. Int Endod J. 2002.

40. Haapasalo M, Shen Y, Wang Z, Gao Y. Irrigation in endodontics. Br Dent J. 2014.

41. Radcliffe CE, Potouridou L, Qureshi R, Habahbeh N, Qualtrough A, Worthington H, et al. Antimicrobial activity of varying concentrations of sodium hypochlorite on the endodontic microorganisms Actinomyces israelii, A. naeslundii, Candida albicans and Enterococcus faecalis. Int Endod J. 2004.

42. Mcdonnell G, Russell AD. Antiseptics and disinfectants: Activity, action, and resistance. Clinical Microbiology Reviews. 1999.

43. Siqueira JF, Rôças IN, Santos SRLD, Lima KC, Magalhães FAC, De Uzeda M. Efficacy of instrumentation techniques and irrigation regimens in reducing the bacterial population within root canals. J Endod. 2002.

44. Marending M, Luder HU, Brunner TJ, Knecht S, Stark WJ, Zehnder M. Effect of sodium hypochlorite on human root dentine - Mechanical, chemical and structural evaluation. Int Endod J. 2007.

45. Violich DR, Chandler NP. The smear layer in endodontics - A review. International Endodontic Journal. 2010.

46. Schilder H. Cleaning and shaping the root canal. Dent Clin North Am. 1974.

47. Boutsioukis C, Gogos C, Verhaagen B, Versluis M, Kastrinakis E, van der Sluis LWM. 
The effect of root canal taper on the irrigant flow: Evaluation using an unsteady Computational Fluid Dynamics model. Int Endod J. 2010.

48. Boutsioukis C, Gogos C, Verhaagen B, Versluis M, Kastrinakis E, van der Sluis LWM. The effect of apical preparation size on irrigant flow in root canals evaluated using an unsteady Computational Fluid Dynamics model. Int Endod J. 2010.

49. Sedgley CM, Nagel AC, Hall D, Applegate B. Influence of irrigant needle depth in removing bioluminescent bacteria inoculated into instrumented root canals using real-time imaging in vitro. Int Endod J. 2005.

50. Boutsioukis C, Verhaagen B, Versluis M, Kastrinakis E, Wesselink PR, van der Sluis LWM. Evaluation of Irrigant Flow in the Root Canal Using Different Needle Types by an Unsteady Computational Fluid Dynamics Model. J Endod. 2010.

51. Al-Hadlaq SM, Al-Turaiki SA, Al-Sulami U, Saad AY. Efficacy of a New Brush-Covered Irrigation Needle in Removing Root Canal Debris: A Scanning Electron Microscopic Study. J Endod. 2006.

52. Ruddle CJ. Microbrush for endodontic use. Washington, DC United States Pat 6,179,617; 2001. 2001.

53. Parente JM, Loushine RJ, Susin L, Gu L, Looney SW, Weller RN, et al. Root canal debridement using manual dynamic agitation or the EndoVac for final irrigation in a closed system and an open system. Int Endod J. 2010.

54. Burleson A, Nusstein J, Reader A, Beck M. The In Vivo Evaluation of Hand/Rotary/Ultrasound Instrumentation in Necrotic, Human Mandibular Molars. J Endod. 2007.

55. Basrani B. Irrigation in endodontic treatment. The Alpha omegan. 2011.

56. Tronstad L, Barnett F, Schwartzben L, Frasca P. Effectiveness and safety of a sonic vibratory endodontic instrument. Dent Traumatol. 1985.

57. Carver K, Nusstein J, Reader A, Beck M. In Vivo Antibacterial Efficacy of Ultrasound after Hand and Rotary Instrumentation in Human Mandibular Molars. J Endod. 2007.

58. Migoun NP, Azouni MA. Filling of one-side-closed capillaries immersed in liquids. J Colloid Interface Sci. 1996.

59. Vernon-Parry KD. Scanning electron microscopy: an introduction. III-Vs Rev. 2002.

60. Stadtländer CTK-H. Scanning electron microscopy and transmission electron microscopy of mollicutes: challenges and opportunities. Res Educ Top Microsc. 2007.

61. Freeman GH, Gomez KA, Gomez AA. Statistical Procedures for Agricultural Research. Biometrics. 2006.

62. Tabrizizadeh M, Shareghi A. The effect of preparation size on efficacy of smear layer removal; a scanning electron microscopic study. Iran Endod J. 2015. 
63. Shen Y, Gao Y, Qian W, Ruse ND, Zhou X, Wu H, et al. Three-dimensional Numeric Simulation of Root Canal Irrigant Flow with Different Irrigation Needles. J Endod. 2010.

64. Jiang LM, Verhaagen B, Versluis M, Langedijk J, Wesselink P, Van Der Sluis LWM. The influence of the ultrasonic intensity on the cleaning efficacy of passive ultrasonic irrigation. J Endod. 2011.

65. Sabins RA, Johnson JD, Hellstein JW. A comparison of the cleaning efficacy of short-term sonic and ultrasonic passive irrigation after hand instrumentation in molar root canals. $\mathbf{J}$ Endod. 2003.

66. Kanter V, Weldon E, Nair U, Varella C, Kanter K, Anusavice K, et al. A quantitative and qualitative analysis of ultrasonic versus sonic endodontic systems on canal cleanliness and obturation. Oral Surgery, Oral Med Oral Pathol Oral Radiol Endodontology. 2011.

67. Rödig T, Döllmann S, Konietschke F, Drebenstedt S, Hülsmann M. Effectiveness of different irrigant agitation techniques on debris and smear layer removal in curved root canals: A scanning electron microscopy study. J Endod. 2010. 